\title{
Penerapan Data Mining Dalam Menentukan Pola Ketersediaan Stok Barang Berdasarkan Permintaan Konsumen Di Chykes Minimarket Menggunakan Algoritma Apriori
}

\author{
Idul Fitri Polorida Ginting *, Darjat Saripurna **, Elfitriani ** \\ * Program Studi Sistem Informasi, STMIK Triguna Dharma

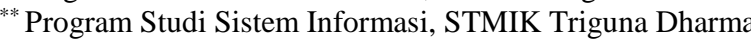

\begin{tabular}{l}
\hline \hline Article Info \\
\hline Article history: \\
Received Jul $12^{\text {th }}, 2020$ \\
Revised Aug $20^{\text {th }}, 2020$ \\
Accepted Oct $26^{\text {th }}, 2020$
\end{tabular}

\section{Keyword:}

Persediaan,

Data Mining,

Apriori,

\begin{abstract}
Persediaan Merupakan suatu yang penting bagi perusahaan karena sebagian besar aktiva perusahaan tertanam pada persediaan. Dengan adanya persediaan perusahaan dapat menjaga kelangsungan hidupnya masalah yang sering dialami dalam akuntansi.Dari hasil penelitian yang dilakukan pada chykes minimarket dalampengecekan ketersedian stok barang pada dasarnya masih bersifat manual, tidak adanya sistem yang dapat memberikan serta memudahkan kepada perusahaan atau bagian gudang.

Dengan masalah tersebut diatas maka dibutuhkan sebuah sistem yang mampu mempemudah serta memberikan informasi kepada perusahaan atau bagian gudang dengan cepat.

Hasil dari penelitian ini mendapatkan suatu keluaran berupa hasil pola ketersediaan stok barang atau persediaa barang pada chykes minimarket dengan metode algoritma apriori.
\end{abstract}

Copyright (C) 2021 STMIK Triguna Dharma. All rights reserved.

\author{
Corresponding Author: \\ Nama : Idul Fitri Polorida Ginting \\ Program Studi : Sistem Informasi \\ STMIK Triguna Dharma \\ Email : fitriginting979@gmail.com
}

\section{PENDAHULUAN}

Inventory (Persediaan Barang) merupakan masalah oprasional yang sering dihadapi oleh perusahaan penjualan barang lainnya [1]. Jika jumlah Persediaan terlalu Sedikit dan permintaan tidak dapat dipenuhi karena kekurangan persedian, hal ini akan mengakibatkan konsumen akan kecewa dan ada kemungkinan konsumen tidak akan kembali lagi untuk membeli barang dikarenakan sudah mendapatkan barang yang lebih menjanjikan dari pihak lain.

Karena itu, manajemen harus bisa memutuskan berapa banyak suatu barang harus disiapkan di stock untuk keperluan penjualan. Selain itu, manejemen juga harus jeli dalam melihat kebutuhan konsumen sehingga mereka merasa puas karena mendapat apa yang mereka butuhkan.

Oleh karena itu untuk mendapatkan persedian yang ideal maka dapat dianalisa dari data penjualan dengan menggunakan Penerapan Data Mining mengunakan Algoritma Apriori.

Data Mining merupakan suatu cabang ilmu kecerdasan buatan (artificial intelligence). Dalam Data Mining terdapat beberapa jenis metode sesuai dengan pemanfaatanya diantaranya : prediksi, asosiasi, klasifikasi, klastering dan estimasi. Dalam metode asosiasi terdapat beberapa teknik diantaranya adalah metode Apriori [2]. Apriori merupakan metode yang memiliki ciri khas yaitu mampu mengasosiasikan data. Konsep penyelesaian apriori adalah melakukan mekanisme perhitungan supoort and conifidence dari suatu hubungan item [3]. Algoridma Apriori ini akan cocok unruk diterapkan bila terdapat beberapa hubungan item yang ingin dianalisa. Salah satunya yang bisa diterapkan adalah dalam bidang promosi dan strategi penjualan.

Oleh karena itu, sehubungan dengan masalah yang dihadapi maka peneliti tertarik mengambil judul "Penerapan Data Mining dalam Menentukan Pola Ketersedian Stok Barang berdasarkan Permintaan Konsumen di Chykes Mini Market Menggunakan Algoritma Apriori”. 


\section{METODE PENELITIAN}

\subsection{Persediaan}

Persediaan Merupakan suatu yang penting bagi perusahaan karena sebagian besar aktiva perusahaan tertanam pada persediaan. Dengan adanya persediaan perusahaan dapat menjaga kelangsungan hidupnya masalah yang sering dialami dalam akuntansi menurut Anwar \& Karamoy (2014) Persediaan adalah pencatatan dan penilaian Oleh karena itu metode pencatatan dan penilaian persediaan barang dapat menguraikan menggambarkan serta membandingkan suatu data sangatlah penting [4].

\subsection{Permintaan Konsumen}

Permintaan adalah berbagai jenis berbagai jumlah barang yang diminta oleh konsumen dalam suatu pasar untuk memenuhi kebutuhan sehari - hari [5].

Permintaan adalah berbagai jenis atau berbagai jumlah barang yang diminta oleh konsumen dalam ke hidupan sehari hari contohnya membeli gula dan sebagian besar konsumen akan membeli kopi atau bubuk teh sehingga perusahan harus menyediakan ketiga produk tersebut dan pelangan tidak akan kecewa karena produk tidak ada.

\subsection{Pengertian Data Mining}

Data Mining adalah Data Mining merupakan suatu proses otomatis terhadap data yang sudah ada. Data yang akan diproses berupa sebuah data yang sangat besar. Tujuan data mining adalah mendapatkan hubungan atau pola yang mungkin memberikan indikasi yang bermanfaat.

\subsection{Knowledge Discovery in Database (KDD)}

\subsubsection{Pengertian in Knowledge Discovery Database (KDD)}

Knowledge Discovery in Database atau KKD adalah keseluruhan proses non-trivial untuk mencari dan mengidentifikasi pola( pattern) dalam data, gimana pola yang ditemukan bersifat sah, baru, dapat bermanfaat dan dapat dimengerti. Sebagai suatu rangkaian proses, data mining dapat dibagi menjadi beberapa tahap proses yang diilustrasikan pada gambar 1 tahap-tahap tersebut bersifat interaktif pemakai terlibat langsung atau dengan perantaraan knowledge base.

\subsection{Algoritma Apriori}

Analisis asosiasi atau Association rule mining adalah teknik data mining untuk menentukan aturan Association antara suatu kombinasi item.

Metodologi dasar analisis terbagi menjadi dua tahap:

1. Analisis pola Frekuensi Tinggi

Tahap ini mencari kombinasi item yang memenuhi syarat minimum dari nilai support dalam database.

Nilai support sebuah item diperoleh dengan rumus berikut:

Support $(\mathrm{A})=\underline{\text { Jumlah Transaksi Mengandung A }}$

Total Transaksi

Sementara itu, nilai Support dari dua item diproleh dari rumus berikut:

Support $(A, B) P(A)$ U B $)$

Support $(\mathrm{A})=\sum$ Jumlah Transaksi Mengandung A

$\sum$ Total Transaksi [6]

2. Pembentukan Aturan Asosiasi

Setelah semua frekunsi tinggi ditemukan, kemudian carirah aturan asosiasi yang memenuhi syarat minimum untuk confidence

Nilai confidence dari aturan $\mathrm{A} \rightarrow \mathrm{B}$ diprolehdari rumus:

Confidence $=\mathrm{P}(\mathrm{B} \mid \mathrm{A})=\sum \underline{\text { Jumlah Transaksi Mengandung A }}$

$\sum$ Total Transaksi

\section{METODOLOGI PENELITIAN}

\subsection{Metode Penelitian}

Pembahasan merupakan tahapan terpenting dalam penelitian yang dilakukan

\subsection{Metode PerancanganSistem}

Dalam konsep penulisan metode perancangan sistem sangatlah penting dalam suatu penelitian. Dalam metode perancangan sistem khususnya software atau perangkat lunak peneliti dapat dapat mengadopsi beberapa metode diantaranya algoritma waterfall atau algoritma air terjun

\subsection{AlgoritmaSistem}

Tahapan-tahapan yang dapat dilakukan dalam membangun data mining ini sebagai berikut:

1. Mencari kombinasi produk terkait yang sering terjadi dari suatu itemset. 
2. Mendefinisikan condition and result.

Dalam menentukan suatu Association rule terdapat suatu ukuran kepercayaan yang didapatkan dari hasil pengolahan data dengan perhitungan tertentu yaitu:

1. Support: Suatu ukuran yang menunjukkan seberapa besar tingkat dominasi

suatu itemset dari seluruh transaksi yang terjadi ukuran ini akan menentukan apakah suatu item layak untuk dilakukan Confident atau tidak.

Mencari nilai suku 1 itemset

Support (A) $=\underline{\text { Jumlah Transaksi Mengandung A }}$

Total Transaksi

Mencari nilai suku 2 itemset

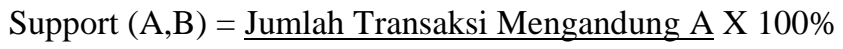

Total Transaksi

2. Confident : Suatu ukuran yang menunjukkan hubungan antara dua item secara kondisional contohnya seberapa sering item Bdibeli jika orang membeli itemA

Confidence $(\mathrm{A} \rightarrow \mathrm{B})=\underline{\text { Jumlah Transaksi Mengandung A }} \times 100 \%$

\subsubsection{Identifikasi data transaksi}

Total Transaksi

Analisis data dilakukan berdasarkan teknik aturan asosiasi menggunakan algoritma apriori dengan beberapa iterasi atau langkah-langkah data yang diambil merupakan data transaksi pembelian pada kipas mini market data tersebut adalah data sampel dari data transaksi pada bulan Januari sampai dengan Juni 2020 sebanyak 50 Transaksi dan dapat dilihat pada tabel berikut:

Tabel 1 Data Transaksi

\begin{tabular}{|c|l|l|}
\hline No & \multicolumn{1}{|c|}{ Tgl Transaksi } & \multicolumn{1}{c|}{ Produk Yang Dibeli } \\
\hline 1. & 01 Jan 2020 & Aqua, Teh botol, Cheetos \\
\hline 2. & 02 Jan 2020 & Aqua, Cheetos, Chitato \\
\hline 3. & 03 Jan 2020 & Teh Botol, Lays, Aqua \\
\hline 4. & 04 Jan 2020 & Aqua, Teh Botol \\
\hline 5. & 05 Jan 2020 & Cocacola, Qtela, Lays \\
\hline 6. & 06 Jan 2020 & Tanggo, Aqua, Lays \\
\hline 7. & 07 Jan 2020 & Tanggo, Aqua, Cheetos \\
\hline 8. & 08 Jan 2020 & Garuda Kacang Atom, Cocacola \\
\hline 9. & 09 Feb 2020 & Bear Band, Maizon, Aqua \\
\hline 10. & 10 Feb 2020 & Aqua, Cheetos, Lays \\
\hline 1. & 11 Feb 2020 & Teh Botol, Cheetos, Lays \\
\hline 12. & 12 Feb 2020 & Cheetos, Lays, Chitato \\
\hline 13. & 13 Feb 2020 & Teh Botol, Maizon, Aqua \\
\hline 14. & 14 Feb 2020 & Qtela, Teh Botol, Cocacola \\
\hline 15. & 15 Feb 2020 & Qtela, Cheetos, Aqua \\
\hline
\end{tabular}

\begin{tabular}{|l|l|l|}
\hline 16. & 16 Feb 2020 & Cheetos, Aqua, Chitato \\
\hline 17. & 17 Mar 2020 & Aqua, Bear Band \\
\hline 18. & 18 Mar 2020 & Bear Band, Teh Botol \\
\hline 19. & 19 Mar 2020 & Teh Botol, Aqua \\
\hline 20. & 20 Mar 2020 & Teh Botol, Aqua \\
\hline 21. & 21 Mar 2020 & Aqua, Maizone \\
\hline 22. & 22 Mar 2020 & Aqua, Lays, Qtela \\
\hline 23. & 23 Mar 2020 & Cheetos, Aqua, Chitato, Tanggo \\
\hline 24. & 24 Mar 2020 & Aqua, Bear Band \\
\hline 25. & 25 April 2020 & Aqua, Bear Band \\
\hline 26. & 26 April 2020 & Aqua, Bear Band, Maizone \\
\hline 27. & 27 April 2020 & Aqua, Bear Band \\
\hline 28. & 28 April 2020 & Aqua, Teh Botol \\
\hline 29. & 29 April 2020 & Bear Band, Maizone \\
\hline
\end{tabular}




\begin{tabular}{|l|l|l|}
\hline 30. & 30 April 2020 & Bear Band, Lays, Qtela \\
\hline 31. & 01 Mei 2020 & Tanggo, Aqua, Lays \\
\hline 32. & 02 Mei 2020 & Chitato, Tanggo, Cheetos \\
\hline 33. & 03 Mei 2020 & Aqua, Bear Band, Maizone \\
\hline 34. & 04 Mei 2020 & Bear Band, Maizone \\
\hline 35. & 05 Mei 2020 & Lays, Qtela, Teh Botol \\
\hline 36. & 06 Mei 2020 & Lays, Qtela, Cheetos, Chitato \\
\hline 37. & 07 Mei 2020 & Teh Botol, Aqua \\
\hline 38. & 08 Jun 2020 & Garuda Kacang Atom, Cocacola \\
\hline 39. & 09 Jun 2020 & Aqua, Cocacola \\
\hline 40. & 10 Jun 2020 & Aqua, Cheetos, Chitato \\
\hline 41. & 11 Jun 2020 & Cocacola, Lays, Qtela \\
\hline 42. & 12 Jun 2020 & Bear Band, Lays, Cheetos \\
\hline 43. & 13 Jun 2020 & Lays, Cheetos, Chitato \\
\hline 44. & 14 Jun 2020 & Qtela, Aqua \\
\hline 45. & 15 Jun 2020 & Aqua, Cheetos, Maizone \\
\hline 46. & 16 Jun 2020 & Tanggo, Aqua, Cocacola \\
\hline 47. & 17 Jun 2020 & Bear Band, Lays, Qtela \\
\hline 48. & 18 Jun 2020 & Aqua, Cheetos, Chitato \\
\hline 49. & 19 Jun 2020 & Aqua, Tanggo \\
\hline 50. & 20 Jun 2020 & Aqua, Teh Botol, Maizone \\
\hline & &
\end{tabular}

\subsubsection{Analisa Pencarian Pola Frekuensi Tinggi}

Dengan nilai support $16 \%$ dari transaksi 50 kemudian dilakukan pencarian nilai support item Tabel 2 Jumlah Tansaksi 1 Itemset

\begin{tabular}{|c|l|c|}
\hline No & \multicolumn{1}{|c|}{ Produk } & Quantity \\
\hline 1. & Aqua & 34 \\
\hline 2. & Teh Botol & 13 \\
\hline 3. & Bear Band & 15 \\
\hline 4. & Tanggo & 7 \\
\hline 5. & Cheetos & 16 \\
\hline 6. & Chitato & 9 \\
\hline 7. & Lays & 16 \\
\hline 8. & Qtela & 9 \\
\hline 9. & Maizone & 8 \\
\hline 10. & Cocacola & 7 \\
\hline
\end{tabular}

Setelah mengetahui jumlah kemunculan 1 itemset, selanjutnya kita mencari jumlah kemunculan 2 itemset

Tabel 3 Transaksi 2 Itemset

\begin{tabular}{|c|l|c|}
\hline No & \multicolumn{1}{|c|}{ 2 Itemset } & Quantity \\
\hline 1. & Aqua, Teh Botol & 8 \\
\hline 2. & Aqua, Bear, Band & 8 \\
\hline 3. & Aqua, Tanggo & 6 \\
\hline 4. & Aqua, Cheetos & 10 \\
\hline 5. & Aqua, Chitato & 6 \\
\hline 6. & Aqua, Lays & 6 \\
\hline 7. & Aqua, Qtela & 2 \\
\hline 8. & Aqua, Maizone & 6 \\
\hline 9. & Aqua, Cocacola & 4 \\
\hline 10. & Teh Botol, Bar Band & 2 \\
\hline 11. & Teh Botol, Cheetos & 2 \\
\hline 12. & Teh Botol, Lays & 3 \\
\hline 13. & Teh Botol, Qtela & 2 \\
\hline 14. & Teh Botol, Cocacola & 1 \\
\hline 15. & Bear Band, Cheetos & 1 \\
\hline 16. & Bear Band, Lays & 4 \\
\hline
\end{tabular}




\begin{tabular}{|c|l|c|}
\hline 17. & Bear Band, Qtela & 2 \\
\hline 18. & Bear Band, Mizone & 4 \\
\hline 19. & Tanggo, Cheetos & 3 \\
\hline 20. & Tanggo, Chitato & 2 \\
\hline 21. & Tanggo, Lays & 2 \\
\hline 22. & Tanggo, Cocacola & 1 \\
\hline 23. & Cheetos, Chitato & 9 \\
\hline 24. & Cheetos, Lays & 6 \\
\hline 25. & Cheetos, Qtela & 2 \\
\hline 26. & Cheetos, Mizone & 1 \\
\hline 27. & Chitato, Lays & 3 \\
\hline 28. & Chitato, Qtela & 1 \\
\hline 29. & Lays, Qtela & 7 \\
\hline 30. & Lays, Cocacola & 2 \\
\hline 31. & Qtela, Cocacola & 3 \\
\hline
\end{tabular}

Mencari support 1 Itemset seperti berikut:

1. Nilai Support 1 Itemset

Dengan Rumus

Support $(\mathrm{A})=\underline{\text { Jumlah Transaksi Mengandung A }}$

Total Transaksi

Tabel 4 Hasil Nilai Support 1 Itemset

\begin{tabular}{|c|l|c|c|c|}
\hline No & \multicolumn{1}{|c|}{ Produk } & Quantity & Support & $* \mathbf{* 0 0 \%}$ \\
\hline 1. & Aqua & 34 & 0.68 & 68 \\
\hline 2. & Teh Botol & 13 & 0.26 & 26 \\
\hline 3. & Bear Band & 15 & 0.3 & 30 \\
\hline 4. & Tanggo & 7 & 0.14 & 14 \\
\hline 5. & Cheetos & 16 & 0.32 & 32 \\
\hline 6. & Chitato & 9 & 0.18 & 18 \\
\hline 7. & Lays & 16 & 0.32 & 32 \\
\hline 8. & Qtela & 9 & 0.18 & 18 \\
\hline 9. & Maizone & 7 & 0.16 & 16 \\
\hline 10. & Cocacola & 7 & 0.14 & 14 \\
\hline
\end{tabular}

Dengan Nilai support Yang Telah ditentukan Minimum 16\% maka hasil dari 1 itemset yang memenuhi ketentuan adalah sebagai berikut:

Tabel 5 Hasil Nilai Support 1 Itemset dengan Minimal

\begin{tabular}{|c|l|c|c|c|}
\hline No & \multicolumn{1}{|c|}{ Produk } & Quantity & Support & $* \mathbf{1 0 0 \%}$ \\
\hline 1 & Aqua & 34 & 0.68 & 68 \\
\hline 2 & Teh Botol & 13 & 0.26 & 26 \\
\hline 3 & Bear Band & 15 & 0.3 & 30 \\
\hline 4 & Cheetos & 16 & 0.32 & 32 \\
\hline 5 & Cheetos & 16 & 0.32 & 32 \\
\hline 6 & Chitato & 9 & 0.18 & 18 \\
\hline 7 & Lays & 16 & 0.32 & 32 \\
\hline 8 & Qtela & 9 & 0.18 & 18 \\
\hline 9 & Maizone & 8 & 0.16 & 16 \\
\hline
\end{tabular}

2. Nilai Support 2 itemset

Dengan Rumus

Support $(\mathrm{A})=\underline{\text { Jumlah Transaksi Mengandung A }}$

Total Transaksi

Tabel 6 Hasil Nilai Support 2 itemset

\begin{tabular}{|c|c|c|c|c|}
\hline No & 2 Itemset & Quantity & Support & $* 100 \%$ \\
\hline 1. & Aqua, Teh Botol & 8 & 0.16 & 16 \\
\hline
\end{tabular}




\begin{tabular}{|c|c|c|c|c|}
\hline 2. & Aqua, Bear, Band & 8 & 0.16 & 16 \\
\hline 3. & Aqua, Tanggo & 6 & 0.12 & 12 \\
\hline 4. & Aqua, Cheetos & 10 & 0.2 & 20 \\
\hline 5. & Aqua, Chitato & 6 & 0.12 & 12 \\
\hline 6. & Aqua, Lays & 6 & 0.12 & 12 \\
\hline 7. & Aqua, Qtela & 2 & 0.04 & 4 \\
\hline 8. & Aqua, Maizone & 6 & 0.12 & 12 \\
\hline 9. & Aqua,Cocacola & 4 & 0.08 & 8 \\
\hline 10. & Teh Botol, Bar Band & 2 & 0.04 & 4 \\
\hline 11. & Teh Botol, Cheetos & 2 & 0.04 & 4 \\
\hline 12. & Teh Botol, Lays & 3 & 0.06 & 6 \\
\hline 13. & Teh Botol, Qtela & 2 & 0.04 & 4 \\
\hline 14. & Teh Botol, Cocacola & 1 & 0.02 & 2 \\
\hline 15. & Bear Band, Cheetos & 1 & 0.02 & 2 \\
\hline 16. & Bear Band, Lays & 4 & 0.08 & 8 \\
\hline 17. & Bear Band, Qtela & 2 & 0.04 & 4 \\
\hline 18. & Bear Band, Mizone & 4 & 0.08 & 8 \\
\hline 19. & Tanggo, Cheetos & 3 & 0.06 & 6 \\
\hline 20. & Tanggo, Chitato & 2 & 0.04 & 4 \\
\hline 21. & Tanggo, Lays & 2 & 0.04 & 4 \\
\hline 22. & Tanggo, Cocacola & 1 & 0.02 & 2 \\
\hline 23. & Cheetos, Chitato & 9 & 0.18 & 18 \\
\hline 24. & Cheetos, Lays & 6 & 0.12 & 12 \\
\hline 25. & Cheetos, Qtela & 2 & 0.04 & 4 \\
\hline 26. & Cheetos, Mizone & 1 & 0.02 & 2 \\
\hline 27. & Chitato, Lays & 3 & 0.06 & 6 \\
\hline 28. & Chitato,Qtela & 1 & 0.02 & 2 \\
\hline 29. & Lays, Qtela & 7 & 0.14 & 14 \\
\hline 30. & Lays, Cocacola & 2 & 0.04 & 4 \\
\hline 31. & Qtela, Cocacola & 3 & 0.06 & 6 \\
\hline
\end{tabular}

Dengan Nilai support Yang Telah ditentukan Minimum 16\% maka hasil dari 2 itemset yang memenuhi ketentuan adalah sebagai berikut:

Tabel 7 Hasil Nilai Support 2 Itemset dengan Minimal

\begin{tabular}{|r|l|c|c|c|}
\hline \multicolumn{1}{|c|}{ No } & \multicolumn{1}{|c|}{ Itemset } & Quantity & Support & $* \mathbf{1 0 0 \%}$ \\
\hline 1. & Aqua, Teh Botol & 8 & 0.16 & 16 \\
\hline 2. & Aqua, Bear, Band & 8 & 0.16 & 16 \\
\hline 3. & Aqua, Cheetos & 10 & 0.2 & 20 \\
\hline 4. & Cheetos, Chitato & 9 & 0.18 & 18 \\
\hline
\end{tabular}

\subsubsection{Pembentukan Aturan Asosiasi ( Asosiation Rule)}

Pembentukan Pola frekuensi - 2 itemset dibentuk dari item-item produk yang memenuhi minimum support, yaitu dengan cara mengkombinasi semua item kedalam pola kombinasi - 2 itemset kemudian hitung nulai supportnya dengan Rumus:

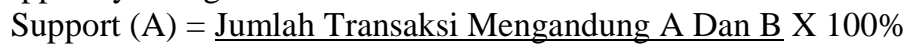

Total Transaksi

Tabel 8 hasil Perhitungan Nilai Confidence Dari 2 Itemset

\begin{tabular}{|c|l|c|c|c|}
\hline No & \multicolumn{1}{|c|}{ 2 Itemset } & Quantity A & Qty A,B & Nilai Confidence \\
\hline 1. & Aqua, Teh Botol & 34 & 8 & 24 \\
\hline 2. & Aqua, Bear, Band & 34 & 8 & 24 \\
\hline 3. & Aqua, Tanggo & 34 & 6 & 18 \\
\hline 4. & Aqua, Cheetos & 34 & 10 & 30 \\
\hline 5. & Aqua, Chitato & 34 & 6 & 18 \\
\hline 6. & Aqua, Lays & 34 & 6 & 18 \\
\hline 7. & Aqua, Qitela & 34 & 2 & 6 \\
\hline 8. & Aqua, Maizone & 34 & 6 & 18 \\
\hline 9. & Aqua, Cocacola & 34 & 4 & 12 \\
\hline 10. & Teh Botol, Aqua & 13 & 8 & 62 \\
\hline
\end{tabular}




\begin{tabular}{|c|c|c|c|c|}
\hline 11. & Teh Botol, Bar Band & 13 & 2 & 15.5 \\
\hline 12. & Teh Botol, Cheetos & 13 & 2 & 15.5 \\
\hline 13. & Teh Botol, Lays & 13 & 3 & 23 \\
\hline 14. & Teh Botol, Qtela & 13 & 2 & 15.5 \\
\hline 15. & Teh Botol, Cocacola & 13 & 1 & 8 \\
\hline 16. & Bear Band, Aqua & 15 & 8 & 53 \\
\hline 17. & Bear Band, Teh Botol & 15 & 2 & 13 \\
\hline 18. & Bear Band, Cheetos & 15 & 1 & 7 \\
\hline 19. & Bear Band, Lays & 15 & 4 & 27 \\
\hline 20. & Bear Band, Qtela & 15 & 2 & 13 \\
\hline 21. & Bear Band, Mizone & 15 & 4 & 27 \\
\hline 22. & Tanggo, Aqua & 7 & 6 & 86 \\
\hline 23. & Tanggo, Cheetos & 7 & 3 & 43 \\
\hline 24. & Tanggo, Chitato & 7 & 2 & 29 \\
\hline 25. & Tanggo, Lays & 7 & 2 & 29 \\
\hline 26. & Tanggo, Cocacola & 7 & 1 & 14 \\
\hline 27. & Cheetos, Aqua & 16 & 10 & 62.5 \\
\hline 28. & Cheetos, Teh Botol & 16 & 2 & 12.5 \\
\hline 29. & Cheetos, Bar Band & 16 & 1 & 6 \\
\hline 30. & Cheetos, Tanggo & 16 & 3 & 19 \\
\hline 31. & Cheetos, Chitato & 16 & 9 & 56 \\
\hline 32. & Cheetos, Lays & 16 & 6 & 37.5 \\
\hline 33. & Cheetos,Qtela & 16 & 2 & 12.5 \\
\hline 34. & Cheetos, Mizone & 16 & 1 & 6 \\
\hline 35. & Chitato, Aqua & 9 & 6 & 67 \\
\hline 36. & Chitato, Tanggo & 9 & 2 & 22 \\
\hline 37. & Chitato, Cheetos & 9 & 9 & 100 \\
\hline 38. & Chitato, Lays & 9 & 3 & 33 \\
\hline 39. & Chitato, Qtela & 9 & 1 & 11 \\
\hline 40. & Lays, Aqua & 16 & 6 & 37.5 \\
\hline 41. & Lays, Teh Botol & 16 & 3 & 19 \\
\hline 42. & Lays, Bear Band & 16 & 4 & 25 \\
\hline 43. & Lays, Tanggo & 16 & 2 & 12.5 \\
\hline 44. & Lays, Cheetos & 16 & 6 & 37.5 \\
\hline 45. & Lays, Chitato & 16 & 3 & 33 \\
\hline 46. & Lays, Qtela & 16 & 7 & 44 \\
\hline 47. & Lays, Cocacola & 16 & 2 & 12.5 \\
\hline 48. & Qtela, Aqua & 9 & 2 & 22 \\
\hline 49. & Qtela, Teh Botol & 9 & 2 & 22 \\
\hline 50. & Qtela, Bear Band & 9 & 2 & 22 \\
\hline 51. & Qtela, Cheetos & 9 & 2 & 22 \\
\hline 52. & Qtela, Chitato & 9 & 1 & 11 \\
\hline 53. & Qtela, Lays & 9 & 7 & 78 \\
\hline 54. & Qtela, Cocacola & 9 & 3 & 33 \\
\hline 55. & Mizone, Aqua & 8 & 6 & 75 \\
\hline 56. & Mizone, Bear Band & 8 & 4 & 50 \\
\hline 57. & Mizone, Cheetos & 8 & 1 & 12.5 \\
\hline 58. & Cocacola, Aqua & 7 & 4 & 57 \\
\hline 59. & Cocacola,Teh Botol & 7 & 1 & 14 \\
\hline 60. & Cocacola, Tanggo & 7 & 1 & 14 \\
\hline 61. & Cocacola, Lays & 7 & 2 & 29 \\
\hline 62. & Cocacola, Qtela & 7 & 3 & 43 \\
\hline
\end{tabular}


Selanjutnya kita tentukan nilai minimum Confidence $=60 \%$ maka aturan asosiasi yang terbentuk adalah sebagai berikut :

Tabel 9 Hasil Nilai Confidence yang Memenuhi Minimum Confidence

\begin{tabular}{|c|l|l|l|l|}
\hline No & \multicolumn{1}{|c|}{ 2 Itemset } & Quantity A & $\begin{array}{c}\text { Qty } \\
\text { AnB }\end{array}$ & $\begin{array}{c}\text { Nilai Confidence } \\
\text { dan } * \mathbf{1 0 0 \%}\end{array}$ \\
\hline 1. & Teh Botol, Aqua & 13 & 8 & 62 \\
\hline 2. & Tanggo, Aqua & 7 & 6 & 86 \\
\hline 3. & Cheetos, Aqua & 16 & 10 & 62.5 \\
\hline 4. & Chitato, Aqua & 9 & 6 & 67 \\
\hline 5. & Chitato, Cheetos & 9 & 9 & 100 \\
\hline
\end{tabular}

Maka Nilai untuk Support dan Confidence dengan pola kombinasi 2 itemset dengan minimum Support $=16 \%$ dan minimum Confidence $=60 \%$ adalah sebagai berikut:

Tabel 10 Hasil dari Perhitungan Support dan Confidence

\begin{tabular}{|c|l|l|l|}
\hline No & \multicolumn{1}{|c|}{ 2 Itemset } & \multicolumn{1}{|c|}{ Support } & \multicolumn{1}{c|}{ Confidence } \\
\hline 1. & Teh Botol, Aqua & $16 \%$ & $62 \%$ \\
\hline 2. & Bear Band, Aqua & $16 \%$ & $53 \%$ \\
\hline 3. & Aqua, Cheetos & $20 \%$ & $62.5 \%$ \\
\hline 4. & Cheetos,Chitato & $18 \%$ & $100 \%$ \\
\hline 5. & Aqua Tanggo & $22.5 \%$ & $86 \%$ \\
\hline 6. & Chitato, Aqua & $18 \%$ & $67 \%$ \\
\hline
\end{tabular}

Dari Tahap - Tahap Yang dilakukan maka item yang memenuhi minimum Support dan beserta hasil dari confidence berdasarkan aturan asosiasi yang terbentuk maka diambil kesimpulan sebagai berikut:

1. Jika konsumen membeli Teh Botol maka akan dipasangkan bersama Aqua support $16 \%$ dan confidence $62 \%$ dan perusahan / gudang harus membuat stok barang tersebut.

2. Jika konsumen membeli Bear Brand maka akan dipasangkan bersama Aqua support $16 \%$ dan confidence $60 \%$ dan perusahan / gudang harus membuat stok barang tersebut.

3. Jika konsumen membeli Chitato maka akan dipasangkan bersama Cheetos support $18 \%$ dan confidence $100 \%$ dan perusahan / gudang harus membuat stok barang tersebut.

4. Jika konsumen membeli Aqua maka akan dipasangkan bersama Tango support $22.5 \%$ dan confidence $86 \%$ dan perusahan / gudang harus membuat stok barang tersebut.

5. Jika konsumen membeli Chitato maka akan dipasangkan bersama Aqua support $18 \%$ dan confidence $67 \%$ dan perusahan / gudang harus membuat stok barang tersebut.

\section{PEMODELAN DAN PERANCANGAN SISTEM}

Pemodelan untuk perancangan dan pengembangan sistem yang akan dirancang dan digambarkan dalam bentuk use case diagram, activity diagram dan class diagram.

\section{PENGUJIAN DAN IMPLEMENTASI}

Implementasi merupakan langkah yang digunakan untuk mengoperasikan sistem yang akan dibangun. Dalam bab ini akan dijelaskan bagaimanamenjalankansistem yang telah dibangun tersebut. Dibawah ini merupakan tampilan dari implementasi data mining dengan metode apriori yaitu:

1. Tampilan Form Login

Berikut ini adalah tampilan halaman login:

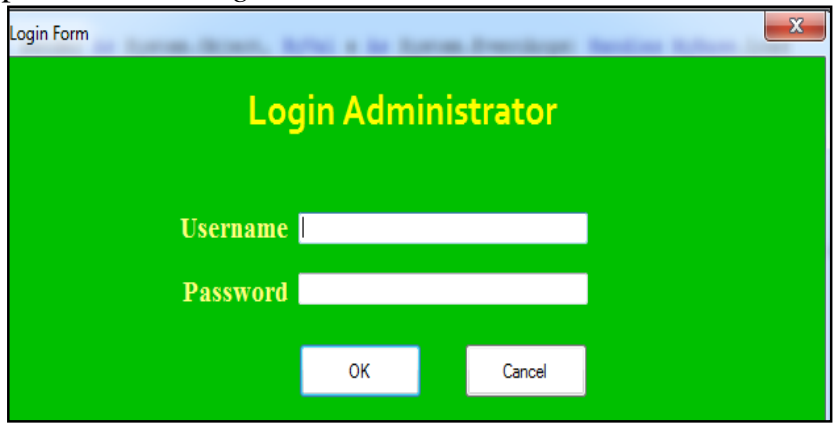

Gambar 1 Tampilan Login

2. Tampilan Menu Utama

Berikut ini adalah tampilan halaman menu utama: 


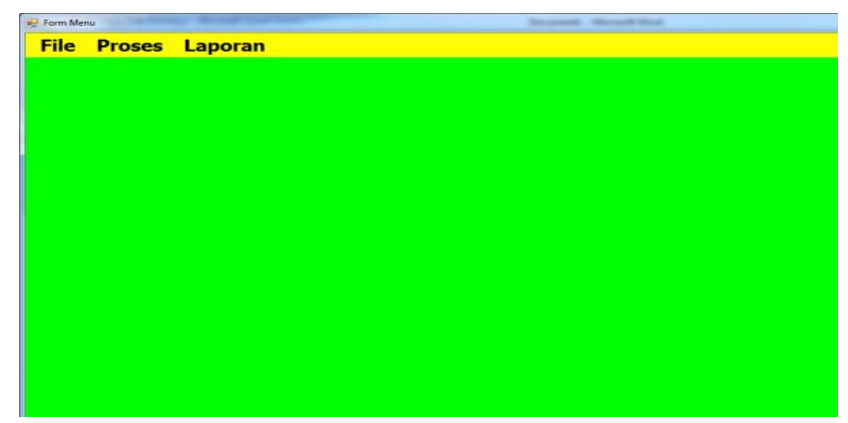

3. Tampilan Halaman Data Barang

\section{Gambar 2 Tampilan Menu Utama}

Berikut ini adalah tampilan halaman input dan import data barangadalah sebagai berikut:

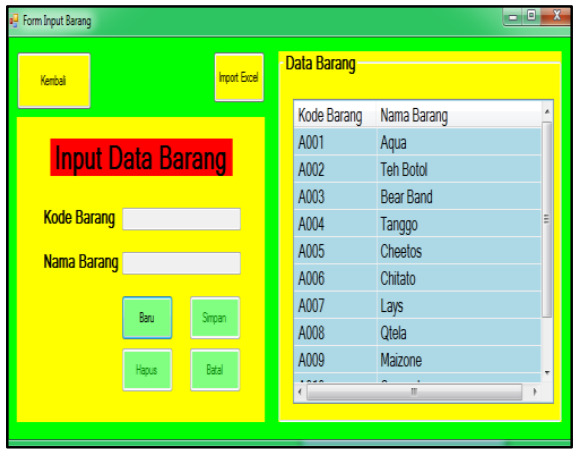

Gambar 3 Tampilan Input Barang

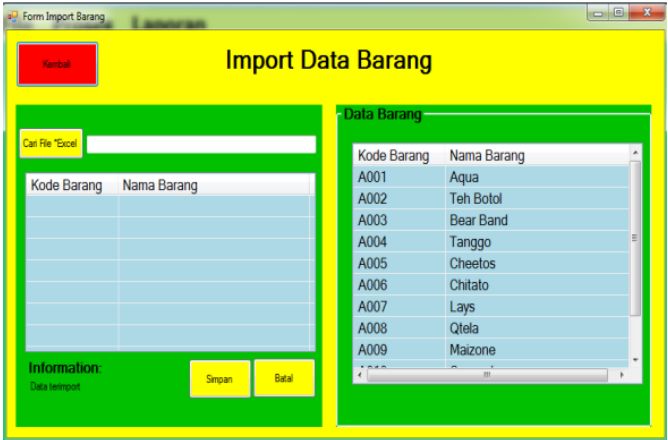

Gambar 4 Tampilan Import Barang

4. Tampilan Halaman Data Transaksi

Berikut ini adalah tampilan dari halaman input dan import data transaksi adalah sebagai berikut:

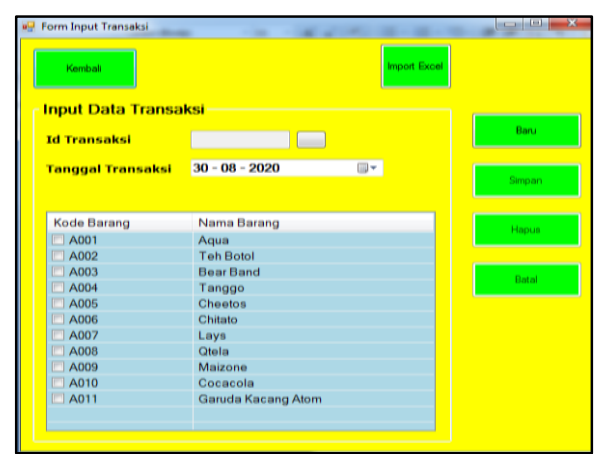

Gambar 5 Tampilan Input Transaksi

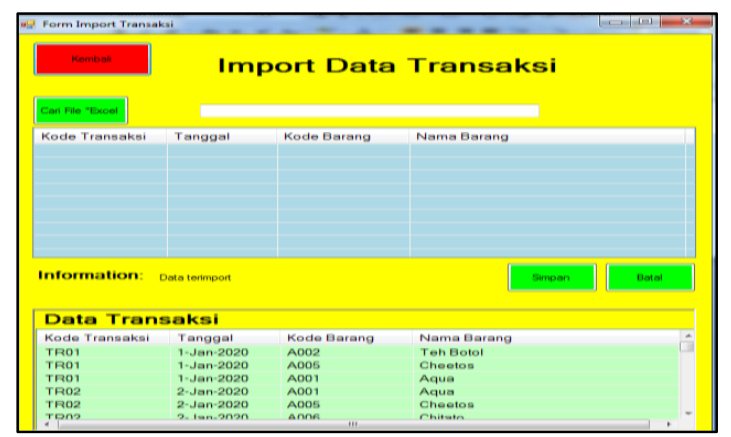

Gambar 6 Tampilan Import Transaksi

5. Tampilan Halaman Proses

Berikut ini adalah tampilan dari halaman proses apriori ke 1 dan ke 2 adalah sebagai berikut: 


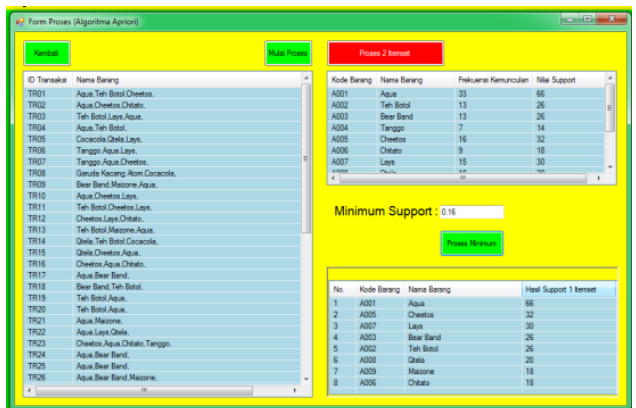

Gambar 7 Tampilan Proses Ke 1

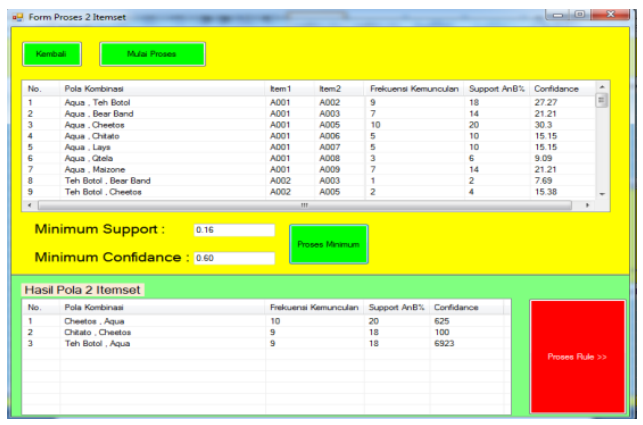

Gambar 8 Tampilan Proses Ke 2

Gambar 4.7 Tampilan Halaman Proses Diagnosa

6. Tampilan Halaman Laporan

Berikut ini adalah tampilan dari hasil perhitungan tersebut:

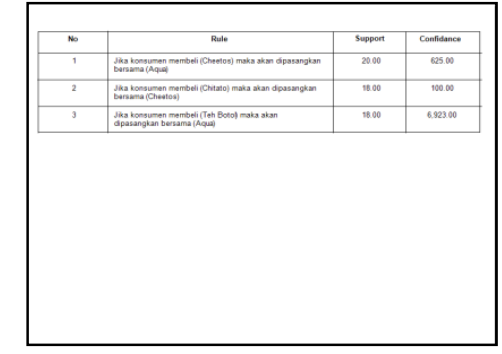

Gambar 9 Tampilan Laporan Kombinasi

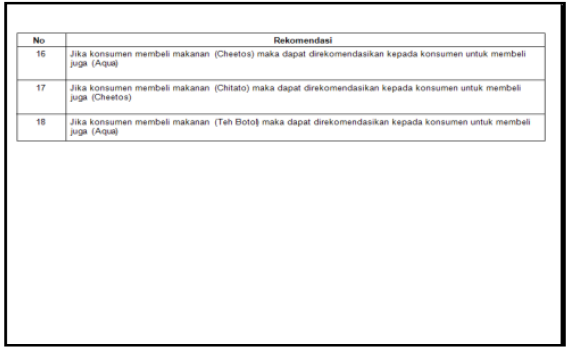

Gambar 10 Tampilan Laporan Rekomendasi

\section{KESIMPULAN}

Jadi kesimpulan yang dapat disimpulkan adalah:

1. Permasalahan yang terjadi berkenaan dengan ketersedian barang yang merupakan frequen itemset dalam Algoritma Apriori Sangat tepat penerapannya dalam data mining dalam teknik Assosiation Rule.

2. Pengujian terhadap sistem ini untuk melihat sejauh mana sisem didalam pemecahaan permasalaahan dalam penentuan produk terkait yang terjadi Chykes Mini Market dilakukan dengan mengetahui stok barang makanan ringan / snack dan minuman agar Perusahaan mengetahui barang yang mana saja yang di stok / disediakan.

\section{UCAPAN TERIMA KASIH}

Puji syukur kehadirat Tuhan Yang Maha Esa atas izin-Nya yang telah melimpahkan rahmat dan karuniaNya sehingga dapat menyelesaikan jurnal ilmiah ini. Pada kesempatan ini diucapkan terima kasih yang sebesarbesarnya kepada kedua Orang Tua tercinta yang selama ini memberikan do'a dan dorongan baik secara moril maupun materi sehingga dapat terselesaikan pendidikan dari tingkat dasar sampai bangku perkuliahan dan terselesaikannya jurnal ini. Di dalam penyusunan jurnal ini, banyak sekali bimbingan yang didapatkan serta arahan dan bantuan dari pihak yang sangat mendukung. Oleh karena itu dengan segala kerendahan hati, diucapkan terima kasih yang sebesar-besarnya kepadakepada ketua yayasan STMIK Triguna Dharma, kepada Bapak Darjat Saripurna, S.Kom., M.Komselaku dosen pembimbing 1, kepada Ibu Elfitriani, S.Pd., M.Siselaku dosen pembimbing 2, kepada kedua orang tua saya yang selalu memberikan dukungan dan doa kepada saya serta tidak lupa kepada teman-teman saya seperjuangan.

\section{REFERENSI}

[1] G. Rabbany, P. Studi, T. Informatika, and U. D. Nuswantoro, "Analisis aturan asosiasi menggunakan algoritma apriori untuk menentukan inventori apotek," no. 5.

[2] M. Rizaluddin, "PERANCANGAN SISTEM INFORMASI PERSEDIAAN BARANG," vol. 4, no. 2, pp. 325 $333,2019$.

[3] Lismardiana, H.Mawengkang, E. Budiarti,"Jurnal Teknologi dan Komunikasi: Pengembagan Algoritma Apriori Untuk Pengambilan Keputusan," vol. 4, no. 2, pp 110-121, 2015.

[4] G. Amaral et al., “No 主観的健康感を中心とした在宅高齢者における健康関連指標に関する共分散構造 分析Title," J. Petrol., vol. 369, no. 1, pp. 1689-1699, 2013, doi: 10.1017/CBO9781107415324.004.

[5] G. Rabbany, P. Studi, T. Informatika, and U. D. Nuswantoro, "Analisis aturan asosiasi menggunakan algoritma apriori untuk menentukan inventori apotek," no. 5.

[6] S. Wahyuni, "Implementasi Data Mining dalam Memprediksi Stok Barang Menggunakan Algoritma Apriori," vol. 5 , pp. 67-71, 2018. 